\title{
UPAYA MENINGKATKAN HASIL BELAJAR SISWA PADA MATA PELAJARAN MATEMATIKA MATERI KECEPATAN PENERAPAN MODEL REALISTIK MATHEMATICS EDUCATION ( RME ) SISWA KELAS V UPT. SD NEGERI 09 BARINGIN
}

\author{
AFNI MULYATI \\ afnimulyati09@gmail.com
}

\begin{abstract}
This study aims to determine (1) Student learning outcomes in learning mathematics material speed before using the RME (Realistic Mathematics Education) model in class V UPT. SD Negeri 09 Baringin. (2) The application of the RME (Realistic Mathematic Education) model can improve learning outcomes in mathematics subject matter speed in class V UPT. SD Negeri 09 Baringin. (3) Student learning outcomes in learning mathematics material speed after using the RME (Realistic Mathematics Education) model in class V UPT. SD Negeri 09 Baringin. This type of research is in the form of PTK, with the research subject of class V UPT. SD Negeri 09 Baringin. consists of 35 people. Based on the results of the study, it can be concluded that: (1) the learning outcomes before the action results in the mean value of the pre-test was 67.72. Students who completed were 48.57\% (17 students). (2) student learning outcomes after applying the RME (Realistic Mathematics Education) Model in the first cycle the average score was 74 or as much as $65.71 \%$ (23 students) were complete. Meanwhile, the average score of the second cycle students increased again to 82.86 or as much as $85.72 \%$ (30 students) who completed learning. It can be concluded that the RME (Realistic Mathematics Education) Model can improve students' Mathematics learning outcomes on Speed only in class V UPT. SD Negeri 09 Baringin. Keywords: Improving Student Learning Outcomes and Application of the RME model.
\end{abstract}

Abstrak: Penelitian ini bertujuan untuk mengetahui (1) Hasil belajar siswa pada pembelajaran matematika materi kecepatan sebelum menggunakan model RME (Realistik Mathematics Education) di kelas V UPT. SD Negeri 09 Baringin. (2) Penerapan model RME ( Realistik Mathematic Education ) dapat meningkatkan hasil belajar pada pelajaran matematika materi kecepatan di kelas V UPT. SD Negeri 09 Baringin. (3) Hasil belajar siswa pada pembelajaran matematika materi kecepatan sesudah menggunakan model RME (Realistik Mathematics Education) di kelas V UPT. SD Negeri 09 Baringin. Jenis penelitian berupa PTK, dengan subjek penelitian kelas V UPT. SD Negeri 09 Baringin. terdiri dari 35 orang. Berdasarkan hasil penelitian dapat diambil kesimpulan bahwa: (1) hasil belajar sebelum tindakan hasil nilai rata-rata pada pre test adalah 67,72. Siswa yang tuntas adalah 48,57\% (17 peserta didik). (2) hasil belajar siswa setelah diterapkan Model RME (Realistik Mathematics Education) pada siklus I nilai rata-rata menjadi 74 atau sebanyak 65,71\% (23 peserta didik) yang tuntas. Sedangkan nilai rata-rata siswa siklus II meningkat lagi menjadi 82,86 atau sebanyak $85,72 \%$ (30 peserta didik) yang tunta belajar. .Dapat disimpulkan bahwa Model RME (Realistik Mathematics Education) dapat meningkatkan hasil belajar Matematika siswa pada materi Kecepatan hanya di kelas V UPT. SD Negeri 09 Baringin.

Kata kunci: Peningkatan Hasil Belajar Siswa Dan Penerapan model RME. 


\section{A. Pendahuluan}

Masalah utama pada pendidikan di indonesia adalah rendahnya hasil belajar siswa di sekolah sementara perkembangan Ilmu Pengetahuan dan Teknologi (IPTEK) yang pesat saat ini membuat penguasaan pengetahuan matematika sangat perlu untuk dipahami dan dikuasai dengan baik oleh siswa. Dewasa ini dalam kehidupan sehari-hari manusia sudah lazim berpikir cepat, logis, serta mempergunakan teknologi yang lebih cepat dan logis terdapat pada matematika. Tidak dapat dipungkiri bahwa tidak ada orang yang tidak memerlukan bantuan matematika dalam kehidupan sehari-hari. Pendidikan merupakan suatu cara untuk membentuk kemampuan manusia dengan menggunakan alat fikiran/rasional sebagai jawaban dalam menghadapi masalah-masalah yang akan dialami di masa mendatang. Dengan pendidikan itulah manusia bisa bertahan hidup dan bersosialisasi diderasnya perkembangan zaman sekarang ini.

Menurut Rosdiana. A. Bakar (2012: 9) Pendidikan adalah daya upaya untuk memberi tuntunan pada segala kekuatan kodrat yang ada pada anak, agar mareka baik sebagai individu maupun sebagai anggota masyarakat, dapat mencapai keselamatan dan kebahagian hidup lahir dan bathin yang setinggi-tingginya. Pendidikan merupakan pertolongan yang diberikan oleh orang dewasa yang bertanggung jawab terhadap perkembangan anak untuk membentuk anak menjadi lebih dewasa sangatlah penting sehingga proses yang dilakukan ialah memberikan pendidikan. Rosdiana. A. Bakar (2012: 19). Tujuan pendidikan adalah sebagai suatu proses mencakup semua bentuk aktifitas yang membantu anak didik menyesuaikan diri dalam kehidupan sosial, meneruskn adat istiadat, kebiasaan, peraturan, hukum kepercayaan, keyakinan, bahasa, bentuk-bentuk kelompok sosial dan satu prestasi ke generasi berikutnya. Bakar Dengan memberikan contoh hidup bersosial di lingkungan sekolah dan memperkenalakan serta mengajarkan adat-istiadat yang telah ada dan peraturanperaturan yang telah berlaku disekolah serta lingkungan masyarakat maka dapat tercapai tujuan pendidikan yang diinginkan sehingga dapat membentuk perserta didik yang akan mencintai dan menjaga negara dengan apa yang telah ditanamkan padanya.

Matematika sangat erat kaitanya dengan kegiatan sehari-hari manusia, baik dari hal sederhana sampai hal yang membutuhkan suatu pemikiran lebih. Matematika bukanlah suatu ilmu yang terisolasi dari kehidupan manusia, melainkan matematika justru muncul dari dan berguna untuk kehidupan sehari-hari kita. Suatu pengetahuan bukan sebagai objek yang terpisah melainkan sebagai suatu bentuk penerapan dalam kehidupan. Suatu ilmu pengetahuan akan sulit untuk kita terapkan jika ilmu pengetahuan tersebut tidak bermakna bagi kita. Kebermaknaan ilmu pengetahuan juga menjadi aspek utama dalam proses belajar. Proses belajar akan terjadi jika pengetahuan yang dipelajari bermakna bagi pembelajaran (Freudental, 1991 dalam buku Riyadi Wijaya, 2011: 3). Pembelajaran matematika terfokus pada guru, sehingga siswa cenderung pasif. Guru yang mendominasi kegiatan pembelajaran dikelas. Selain itu masih terdapat metode konvensional yang masih diterapkan, membuat suasana pembelajaran di kelas menonton, guru hanya menjelaskan materi pembelajaran, memberikan rumus tersebut. Pembelajaran yang demikian tidak kondusif sehingga membuat siswa menjadi sasaran pembelajaran yang pasif, dan hanya menerima konsep dari guru saja. Tidak semua siswa dapat menghapal dengan baik tanpa memahami konsep . hal ini berimplikasi pada hasil belajar siswa yang rendah atau tidak sesuai dengan target yang ingin dicapai dalam suatu proses pembelajaran. 
Kompetensi pelajaran matematika turut serta dalam menentukan hasil belajar. Kompetensi pelajaran matematika cukup luas anatra konsep yang satu dengan konsep awal dengan tuntas, maka untuk tingkat selajutnya akan sulit pula untuk mengikuti pelajaran tersebut. Sebagai contoh tentang konsep perkalian. Konsep perkalian sebagai penjumalahan berulang dikelas II, namun apabila seseorang anak belum bisa memahami dan mengusai konsep ini dengan baik dan sudah naik ketingkat selanjutnya, maka anak akan semakin kesulitan sehingga akan membentuk persepsi dalam dirinya bahwa matematika itu pelajaran yang sulit. Menurut Endang Setyo Winarmi dkk (2016: 113) tujuan belajar matematika yang tertera dalam kurikulum mata pelajaran matematika sekolah pada semua jenjang pendidikan, yaitu : mengarah pada kemampuan siswa pada pemecahan masalah yang dihadapi dalam kehidupan sehari-hari. Dengan diberilakunnya kurikulum baru disekolah diharapkan dapat membenahi model pembelajaran yang selama ini dilakukan sehingga dapat menjadikan siswa, kreatif, dan inovatif dalam menanggapi setiap pelajaran yang diajarkan.

Seorang guru dituntut untuk melaksanakan proses pembelajaran yang menunjang pengetahuan, minat dan bakat siswa guru yang kurang memiliki intelegensi, sosial dan keterampilan akan mengalami kesulitan dalam menjalankan proses pembelajaran. Rendahnya hasil belajar matematika ini dipengaruhi oleh banyak faktor, antara lain proses pembelajaranya, siswa, guru, lingkungan kelas, maupun materinya sendiri. Dilihat dari proses pembelajarannya, yaitu pembelajaran masih bersifat konvensioanal, dimana guru kebanyakan menggunakan metode ceramah dan siswa diminta untuk mendengarkan dan menghafal rumus-rumus yang sudah ada. Padahal jika hanya menghafal saja tanpa tahu konsepnya maka siswa akan lebih mudah untuk melupakan rumus tersebut. Permasalahan serupa tentang rendahnya hasil belajar matematika juga terjadi pada siswa kelas V UPT. SD Negeri 09 Baringin. Guru kurang menggunakan Model yang dapat membuat siswa aktif dan kreatif dalam menyelesaikan masalah, guru hanya menggunakan metode ceramah sehingga proses pembelajaran terkesan satu arah, membosankan dan akhirnya siswa mendapat hasil belajar yang rendah.

Berdasarkan pengamatan pada hasil pembelajaran matematika di kelas V UPT. SD Negeri 09 Baringin., diperoleh data mengenai hasil belajar yang rendah. Rendahnya hasil belajar ini dilihat dari hasil peroleh ujian harian. Siswa banyak menganggap sulit dan membosankan sehingga penggunaan konsep pada materi yang dipelajari kurang mampu diterapkan dalam memecahkan masalah pada kehidupan nyata. Sehingga semakin membuat pelajaran matematika kurang disenangi dan hanya sekedar bersifat hapalan. Dan ketika soal siswa mulai bingung ditambah lagi siswa kurang mampu menghubungkan antara yang siswa pelajari dengan pemanfaatan dalam kehidupan nyata. Pada data tersebut jumlah siswa kelas $\mathrm{V}$ terdapat 35 orang yang jumlah nilainya 2370 yaitu dari hasil jumlah keseluruhan nilai. Nilai tertinggi siswa mencapai 90 dan nilai terendahnya mencapai 30. Dan nilai rata- rata itu dari hasil jumlah keseluruhan dibagikan jumlah siswa maka hasilnya 67,71 dapat dilihat bahwa 51,43\% siswa belum mencapai Kriteria Ketuntansan Minimum (KKM), hal ini ditunjukan dengan nilai rata-rata kelas yang masih di bawah KKM. Padahal jika dilihat dari penetapan KKM di UPT. SD Negeri 09 Baringin itu masih rendah yaitu 75 .

Solusi untuk meningkatkan hasil belajar matematika siswa kelas V UPT. SD Negeri 09 Baringin adalah menerapkan pendekatan matematika realistik. Suatu ilmu pengetahuan akan bermakna bagi pembelajar jika proses belajar melibatkan masalah realistik. Salah satu pendekatan pembelajaran yang menekankan pada EISSN 2657-0289 $\quad$ Lembaga Penelitian dan Penerbitan Hasil Penelitian Ensiklopedia $\quad 99$ 
kebemaknaan ilmu pengetahuan adalah pendidikan matematika realistik (Realistic Mathematics Education) strategi pembelajaran menggunakan pendekatan realistik menekankan akan pentingnya konteks nyata yang dikenal siswa dan proses kontruksi pengetahuan matematika oleh siswa sendiri, dapat memberikan kesempatan yang aktif dan kreatif. Siswa lebih mudah mengingat jika mareka membangun pengetahuan itu sendiri. Melalui konteks nyata siswa lebih mudah memahami suatu konsep, sehingga dengan pendekatan matematika realistik diharapkan siswa akan lebih memahami dan mengingat materi yang dipelajari. Karena kebermaknaan ilmu pengetahuan juga menjadi aspek utama dalam proses belajar. Dari penjelasan diatas terdapat beberapa hal-hal yang menjadi latar belakang masalah diantaranya: 1) Rendahnya hasil belajar matematika di kelas V pada mata pelajaran matematika; 2) Guru kurang menggunakan model yang dapat membuat siswa aktif dalam pelajaran matematika; dan 3) Siswa kurang berminat mengikuti pelajaran matematika.

Berdasarkan uraian maka peneliti tertarik untuk melakukan penelitian dengan judul ${ }^{\text {ee }}$ Upaya Meningkatkan Hasil Belajar Siswa Pada Mata Pelajaran Matematika Materi Kecepatan Penerapan Model RME (Realistik Mathematics Education) Siswa Kelas V UPT. SD Negeri 09 Baringin. Berdasarkan uraian latar belakang masalah diatas, maka dapat identifikasi masalah dari berbagai faktor sebagai berikut: 1) Rendahnya hasil belajar siswa pada mata pelajaran Matematika di kelas V UPT. SD Negeri 09 Baringin; 2) Model yang digunakan guru belum bervariasi dan masih monoton; 3) Pembelajaran berpusat pada guru, sehingga guru kebih cenderung mendominasi pelajaran; 4) Siswa cenderung pasif dan kurang berminat mengikuti pembelajaran matematika.

\section{B. Metodologi Penelitian}

Jenis penelitian ini adalah penelitian Tindakan Kelas (Classroom Action Reasearch) dengan menggunakan model pembelajaran Realistik (RME; Realistik Mathematics Education) sebagai sasaran utama. Dimana penelitian ini berupaya memaparkan penerapan model pembelajaran Realistik (RME; Realistik Mathematics Education) untuk meningkatkan hasil belajar siswa dengan tujuan memperbaiki/ meningkatkan mutu praktik pembelajaran. Arikunto mengemukakan secara garis besar terdapat 4 tahap yag dilahir melalui pelaksanaan penelitian tindakan kelas, yakni 1) perencanaan (planning).2) Pelakasanaan (Acting), 3) Pengamatan (Observing), dan 4) Refleksi. Sesuai dengan penelitian ini, yaitu penelitian tindakan kelas (Classroom Action Research) yang bertujuan untuk meningkatkan hasil belajar siswa dengan menerapkan model pembelajaran Realistik (RME: Realistik Mathematics Education ) pada materi kecepatan. Maka penelitian ini memiliki beberapa tahap yang merupakan suatu siklus. Tiap siklus dilaksanakan sesuai dengan perubahan yang dicapai. Pada penelitian ini akan dilaksanakan dalam dua siklus, siklus I untuk penelitian pada tahap pertama, dan siklus II sebagai lanjutan atau refleksi dari siklus I. Kedua siklus ini berfungsi untuk melihat ada tidak perubahan hasil belajar siswa setelah melakukan tindakan. Jika tindakan yang diberikan belum berhasil meningkatkan hasil belajar siswa, maka penelitian akan dilanjutkan pada siklus III, dan begitu seterusnya. Subjek dalam penelitian ini adalah siswa kelas V UPT. SD Negeri 09 Baringin yang berjumlah 35 siswa yang terdiri dari 15 peserta didik laki-laki dan 20 peserta didik perempuan. Tempat Penelitian ini dilakukan di UPT. SD Negeri 09 Baringin Kecamatan Lima Kaum Kabupaten Tanah Datar dan penelitian ini dilakukan pada semester genap di kelas V UPT. SD Negeri 09 Baringin. Pada dasarnya, prosedur atau 
langkah-langkah observasi terdiri dari tiga tahap yaitu; pertemuan pendahuluan,pelaksanaan tindakan, observasi, dan refleksi. Tahap ini sering disebut sebagai siklus pengamatan, yang populer dipakai dalam supervisi klinis, baik dalam membimbing calon guru maupun dalam memberikan bantuan profesional bagi guru yang sudah bertugas.

\section{Hasil dan Pembahasan}

Deskripsi Kondisi Awal. Langkah pertama sebelum diterapkannya pembelajaran dengan penerapan model RME (Realistik Mathematics Education) di kelas V UPT. SD Negeri 09 Baringin, dengan tujuan untuk mengetahui kondisi awal siswa terhadap materi kecepatan. Ternyata dari hasil yang dilakukan, siswa kurang mampu menyelesaikan soal tentang materi kecepatan dengan pokok pembahasan kecepatan dan menyelesaikan masalah tentang kecepatan. Kemudian langkah yang diambil peneliti adalah pre tes kepada peserta didik Tes yang diberikan kepada siswa sebelum melakukan perencanaan bertujuan untuk mengetahui kemampuan siswa dalam menyelesaikan soal-soal berupa kecepatan. Hasil belajar siswa pada pelaksanaan pre tes dapa dilihat pada tabel berikut:

\section{Tabel Hasil Belajar Peserta Didik Pre - Test (Pra Siklus)}

\begin{tabular}{|c|c|c|c|c|c|}
\hline \multirow[b]{2}{*}{ No } & \multirow[b]{2}{*}{ Nama Peserta Didik } & \multirow[b]{2}{*}{ KKM } & \multirow[b]{2}{*}{ Nilai } & \multicolumn{2}{|c|}{ Ketuntasan } \\
\hline & & & & Tuntas & Tidak \\
\hline 1 & \begin{tabular}{|l} 
M. Rafly \\
\end{tabular} & 75 & 70 & & $\sqrt{ }$ \\
\hline 2 & \begin{tabular}{|l} 
Fathan Putra Raihan \\
\end{tabular} & 75 & 40 & & $\sqrt{ }$ \\
\hline 3 & Abdu Nabil Almugny, & 75 & 80 & $\sqrt{ }$ & \\
\hline 4 & Al zikra Maulana & 75 & 50 & & $\sqrt{ }$ \\
\hline 5 & Ashila Fitri Dwixani & 75 & 50 & & $\sqrt{ }$ \\
\hline 6 & Aurelia Arori Friska & 75 & 80 & $\sqrt{ }$ & \\
\hline 7 & Aura Cantika Ratu Balgis & 75 & 70 & & $\sqrt{ }$ \\
\hline 8 & Aura Keysha Hendri & 75 & 80 & $\sqrt{ }$ & \\
\hline 9 & Bergah Muriara & 75 & 90 & $\sqrt{ }$ & \\
\hline 10 & Casey Suchira Kurniawan & 75 & 60 & & $\sqrt{ }$ \\
\hline 11 & Chelsea Frea Arta & 75 & 70 & & $\sqrt{ }$ \\
\hline 12 & Fabian Maulana & 75 & 30 & & $\sqrt{ }$ \\
\hline 13 & \begin{tabular}{|l} 
Fahmi Devit \\
\end{tabular} & 75 & 80 & $\sqrt{ }$ & \\
\hline 14 & Fharel Rorisfha,P & 75 & 40 & & $\sqrt{ }$ \\
\hline 15 & Gizkha Narendra & 75 & 80 & $\sqrt{ }$ & \\
\hline 16 & Intan Aurelia Rafani & 75 & 90 & $\sqrt{ }$ & \\
\hline 17 & Kirana Maharani & 75 & 50 & & $\sqrt{ }$ \\
\hline 18 & $\begin{array}{l}\text { Muhammad Athaya } \\
\text { Alesandro }\end{array}$ & 75 & 80 & $\sqrt{ }$ & \\
\hline 19 & \begin{tabular}{|l|} 
Muhammad Vivero Nararya \\
\end{tabular} & 75 & 60 & & $\sqrt{ }$ \\
\hline 20 & Muhammad Habib Pratno. & 75 & 80 & $\sqrt{ }$ & \\
\hline 21 & M. Ziraen Satria & 75 & 50 & & $\sqrt{ }$ \\
\hline 22 & Nafis Ahmad Dzaki & 75 & 90 & $\sqrt{ }$ & \\
\hline 23 & Nafisah Fuada & 75 & 40 & & $\sqrt{ }$ \\
\hline 24 & Putra Askolika Muriz & 75 & 80 & $\sqrt{ }$ & \\
\hline 25 & Putri Alifah & 75 & 70 & & $\sqrt{ }$ \\
\hline 26 & $\begin{array}{l}\text { Raffa Aprilio. } \\
\end{array}$ & 75 & 80 & $\sqrt{ }$ & \\
\hline 27 & \begin{tabular}{|l|} 
Rahma Jelita \\
\end{tabular} & 75 & 80 & $\sqrt{ }$ & \\
\hline 28 & Rafi Nazrin & 75 & 50 & & $\sqrt{ }$ \\
\hline 29 & Salsabila Azatil Ismah & 75 & 80 & $\sqrt{ }$ & \\
\hline 30 & Suci Ramadhana & 75 & 80 & $\sqrt{ }$ & \\
\hline 31 & Yani Putri Zahra & 75 & 30 & & $\sqrt{ }$ \\
\hline 32 & Zalfa_Batrisya Romel & 75 & 80 & $\sqrt{ }$ & \\
\hline 33 & Zivana Utsa Athifa. & 75 & 80 & $\sqrt{ }$ & \\
\hline 34 & Nasyifa.Atika & 75 & 70 & & $\sqrt{ }$ \\
\hline 35 & Shafa Ramadhani Zuhayra & 75 & 70 & & $\sqrt{ }$ \\
\hline \multicolumn{2}{|c|}{ Jumlah } & & 2370 & 17 & 18 \\
\hline \multirow{2}{*}{\multicolumn{2}{|c|}{ Nilai rata-rata }} & & 67,71 & & \\
\hline \multicolumn{3}{|c|}{ Presentase } & & $48,57 \%$ & $51,43 \%$ \\
\hline
\end{tabular}

Dari data tabel di atas, dapat dilihat nilai rata-rata kelas adalah 67,71 peserta didik yang berhasil mencapai KKM atau mendapat nilai $\geq 75$ adalah 17 peserta didik $(48,57 \%)$ dan peserta didik yang belum berhasil mencapai KKM atau mendapatkan 
nilai $<75$ adalah 18 peserta didik $(51,43 \%)$. Berdasarkan hasil pre test maka peneliti dan observer ( Yasnimar, SPd.SD ) sepakat melakukan perbaikan berupa penelitian tindakan kelas untuk meningkatkan hasil belajar peserta didik pada materi kecepatan dengan pokok pembahasan kecepatan dan menyelesaikan masalah tentang kecepatan. Rencana perbaikan ini melalui penerapan model RME (Realistik Mtahematics Education), yang diharapkan dapat meningkatkan hasil belajar dalam proses pembelajaran sehingga hasil belajar juga meningkat.

Deskripsi Hasil Penelitian Siklus I. Setelah kegiatan pembelajaran pada RPP I berlangsung, guru memberikan soal post test yang diikuti oleh 35 orang peserta didik. Adapun Kriteria Ketuntasan Minimal (KKM) yang ditetapkan di UPT. SD Negeri 09 Baringin adalah 75. Skor hasil belajar Post test peserta didik pada siklus I dapat dilihat pada tabel berikut:

Tabel Hasil Evaluasi Peserta Didik Siklus I

\begin{tabular}{|c|c|c|c|c|c|}
\hline \multirow[b]{2}{*}{ No } & \multirow[b]{2}{*}{ Nama Peserta Didik } & \multirow[b]{2}{*}{ KKM } & \multirow[b]{2}{*}{ Nilai } & \multicolumn{2}{|c|}{ Ketuntasan } \\
\hline & & & & Tuntas & Tidak \\
\hline 1 & M. Rafly & 75 & 90 & $\sqrt{ }$ & \\
\hline 2 & Fathan Putra Raihan & 75 & 80 & $\sqrt{ }$ & \\
\hline 3 & Abdu Nabil Almugny & 75 & 50 & & $\sqrt{ }$ \\
\hline 4 & Al zikra Maulana & 75 & 90 & $\sqrt{ }$ & \\
\hline 5 & Ashila Fitri Dwixani & 75 & 60 & & $\sqrt{ }$ \\
\hline 6 & Aurelia Arori Friska & 75 & 60 & & $\sqrt{ }$ \\
\hline 7 & Aura Cantika Ratu Balgis. & 75 & 80 & $\sqrt{ }$ & \\
\hline 8 & Aura Keysha Hendri & 75 & 80 & $\sqrt{ }$ & \\
\hline 9 & Bergah Muriara & 75 & 80 & $\sqrt{ }$ & \\
\hline 10 & Casey Suchira Kurniawan & 75 & 100 & $\sqrt{ }$ & \\
\hline 11 & Chelsea Frea arta & 75 & 60 & & $\sqrt{ }$ \\
\hline 12 & Fabian Maulana & 75 & 80 & $\sqrt{ }$ & \\
\hline 13 & Fahmi Devit & 75 & 40 & & $\sqrt{ }$ \\
\hline 14 & Fharel Roristha,P & 75 & 80 & $\sqrt{ }$ & \\
\hline 15 & Gizkha Narendra & 75 & 50 & & $\sqrt{ }$ \\
\hline 16 & Intan Aurelia Rafani & 75 & 80 & $\sqrt{ }$ & \\
\hline 17 & Kirana Maharani & 75 & 90 & $\sqrt{ }$ & \\
\hline 18 & $\begin{array}{l}\text { Muhammad Athaya } \\
\text { Alesandro. }\end{array}$ & 75 & 60 & & $\sqrt{ }$ \\
\hline 19 & Muhammad Vivero Nararya & 75 & 80 & $\sqrt{ }$ & \\
\hline 20 & Muhammad Habib Pratno & 75 & 70 & & $\sqrt{ }$ \\
\hline 21 & M. Ziraen Satria & 75 & 80 & $\sqrt{ }$ & \\
\hline 22 & Nafis Ahmad Dzaki & 75 & 60 & & $\sqrt{ }$ \\
\hline 23 & Nafisah Fuada & 75 & 90 & $\sqrt{ }$ & \\
\hline 24 & Putra Asksolika Muriz. & 75 & 50 & & $\sqrt{ }$ \\
\hline 25 & \begin{tabular}{|l|} 
Putri Alifah \\
\end{tabular} & 75 & 80 & $\sqrt{ }$ & \\
\hline 26 & Raffa aprilio & 75 & 80 & $\sqrt{ }$ & \\
\hline 27 & Rahma Jelita & 75 & 80 & $\sqrt{ }$ & \\
\hline 28 & Rafi Nazrin & 75 & 80 & $\sqrt{ }$ & \\
\hline 29 & Salsabila Azatil Ismah & 75 & 60 & & $\sqrt{ }$ \\
\hline 30 & Suci Ramadhana & 75 & 90 & $\sqrt{ }$ & \\
\hline 31 & Yani Putri Zahra & 75 & 90 & $\sqrt{ }$ & \\
\hline 32 & Zalfa Batrisya Romel & 75 & 40 & & $\sqrt{ }$ \\
\hline 33 & Zivana Utsa Athifa & 75 & 80 & $\sqrt{ }$ & \\
\hline 34 & Nasyifa Atika & 75 & 90 & $\sqrt{ }$ & \\
\hline 35 & Shafa Ramadhani Zuhayra & 75 & 80 & $\sqrt{ }$ & \\
\hline \multicolumn{2}{|c|}{ Jumlah } & & 2590 & 23 & 12 \\
\hline \multicolumn{2}{|c|}{ Nilai rata-rata } & & 74 & & \\
\hline \multicolumn{4}{|c|}{ Presentase } & $65.71 \%$ & $34.29 \%$ \\
\hline
\end{tabular}

Berdasarkan tabel di atas dapat diketahui bahwa 23 peserta didik $(65,71 \%)$ tuntas belajarnya, sedangkan 12 peserta didik ( 34,29\% ) tidak tuntas. Berdasarkan 
KKM yang ditetapkan di UPT. SD Negeri 09 Baringin bahwa seorang peserta didik dikatakan tuntas belajarnya bila memiliki nilai ketuntasan secara individu minimal 75 . Oleh karena itu, persentase ketuntasan belajar siswa masih berada di bawah $85 \%$ maka hasil belajar dengan penerapan Model RME (Realistik Mathematics Education) untuk siklus I belum mencapai ketuntasan belajar klasikal.

\section{Deskripsi Hasil Penelitian Siklus II}

Tes diberikan oleh peneliti kepada siswa disetiap akhir proses pembelajaran. Tes yang diberikan terdiri dari 10 soal berbentuk choice. Hasil tes belajar siswa yang diperoleh pada siklus II pada materi kecepatan dengan pokok pembahasan kecepatan dan menyelesaikan masalah tentang kecepatan dapat dilihat pada tabelberikut ini:

Tabel

Hasil Evaluasi Peserta Didik Siklus II

\begin{tabular}{|c|c|c|c|c|c|}
\hline \multirow[b]{2}{*}{ No } & \multirow[b]{2}{*}{ Nama Peserta Didik } & \multirow[b]{2}{*}{ KKM } & \multirow[b]{2}{*}{ Nilai } & \multicolumn{2}{|c|}{ Ketuntasan } \\
\hline & & & & $\mathrm{Ya}$ & Tidak \\
\hline 1 & M. Rafly & 75 & 100 & $\sqrt{ }$ & \\
\hline 2 & Fathan Putra Raihan & 75 & 90 & $\sqrt{ }$ & \\
\hline 3 & Abdu Nabil Almugny. & 75 & 60 & & $\sqrt{ }$ \\
\hline 4 & Al zikra Maulana & 75 & 100 & $\sqrt{ }$ & \\
\hline 5 & Ashila Fitri Dwiyani & 75 & 80 & $\sqrt{ }$ & \\
\hline 6 & Aurelia Arori Friska & 75 & 80 & $\sqrt{ }$ & \\
\hline 7 & Aura Cantika Ratu Balqis. & 75 & 80 & $\sqrt{ }$ & \\
\hline$\underline{\underline{8}}$ & 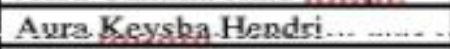 & $75 \ldots$ & $90 \ldots$ & $\ldots 1$ & $\ldots$ \\
\hline 9 & Bergah Muriara & 75 & 80 & $\sqrt{ }$ & \\
\hline 10 & Casey Suchira Kurniawan & 75 & 100 & $\sqrt{ }$ & \\
\hline 11 & Chelsea Frea arta & 75 & 80 & $\sqrt{ }$ & \\
\hline 12 & Fabian Maulana & 75 & 80 & $\sqrt{ }$ & \\
\hline 13 & Fahmi Devit & 75 & 50 & & $\sqrt{ }$ \\
\hline 14 & Fharel Rorisfha, $\mathrm{P}$ & 75 & 80 & $\sqrt{ }$ & \\
\hline 15 & Gizkha Narendra & 75 & 60 & & $\sqrt{ }$ \\
\hline 16 & Intan Aurelia Rafani & 75 & 80 & $\sqrt{ }$ & \\
\hline 17 & Kirana Maharani & 75 & 90 & $\sqrt{ }$ & \\
\hline 18 & $\begin{array}{l}\text { Muhammad Athaya } \\
\text { Alesandro }\end{array}$ & 75 & 80 & $\sqrt{ }$ & \\
\hline 19 & Muhammad Vivero Nararya & 75 & 90 & $\sqrt{ }$ & \\
\hline 20 & Muhammad Habib Pratno & 75 & 80 & $\sqrt{ }$ & \\
\hline 21 & M. Ziraen Satria & 75 & 80 & $\sqrt{ }$ & \\
\hline 22 & Nafis Ahmad Dzaki & 75 & 80 & $\sqrt{ }$ & \\
\hline 23 & Nafisah Fuada & 75 & 100 & $\sqrt{ }$ & \\
\hline 24 & Putra Askolika Muriz & 75 & 70 & & $\sqrt{ }$ \\
\hline 25 & Putri Alifah & 75 & 100 & $\sqrt{ }$ & \\
\hline 26 & Raffa aprilio & 75 & 80 & $\sqrt{ }$ & \\
\hline 27 & Rahma Jelita & 75 & 90 & $\sqrt{ }$ & \\
\hline 28 & Rafi Nazrin & 75 & 80 & $\sqrt{ }$ & \\
\hline 29 & Salsabila Azatil Ismah. & 75 & 80 & $\sqrt{ }$ & \\
\hline 30 & Suci Ramadhana & 75 & 100 & $\sqrt{ }$ & \\
\hline 31 & Yani Putri Zahra & 75 & 90 & $\sqrt{ }$ & \\
\hline 32 & Zalfa Batrisya Romel & 75 & 50 & & $\sqrt{ }$ \\
\hline 33 & Zivana Utsa Athifa & 75 & 80 & $\sqrt{ }$ & \\
\hline 34 & \begin{tabular}{|l|} 
Nasvifa Atika \\
\end{tabular} & 75 & 100 & $\sqrt{ }$ & \\
\hline 35 & Shafa Ramadhani Zuhayra & 75 & 90 & $\sqrt{ }$ & \\
\hline \multicolumn{2}{|c|}{ Jumlah. } & & 2900 & 30 & 5 \\
\hline \multicolumn{2}{|c|}{ Nilai rata-rata } & & 82,86 & & \\
\hline \multicolumn{4}{|c|}{ Presentase } & $85,71 \%$ & $14.29 \%$ \\
\hline
\end{tabular}


Beradasarkan tabel diatas dapat diketahui bahwa nilai siklus II dari 35 siswa pada mata pelajaran Matematika pada sub materi menyelesaikan masalah kecepatan, sebanyak 30 (sekitar 85,71\% mencapai ketuntasan belajar), sedangkan sebanyak 5 orang (sekitar 14,29\% belum tuntas). Nilai terendah adalah 50 dan nilai tertinggi adalah 100. Dengan nilai rata-rata 82,86 dan tingkat ketuntasan klasikal sebesar $85,71 \%$.

\section{Pembahasan Hasil Penelitian}

Model pembelajaran RME (Realistik Mathematics Education) adalah pendidikan matematika yang menekankan kepada siswa untuk menyelesaikan masalah yang ada pada situasi nyata dengan cara mareka sendiri. Dalam proses belajar siswa secara individual disuruh menyelesaikan masalah pada LKPD yang diberi guru dengan caranya sendiri. Siswa diminta untuk membandingkan dan mendiskusikan jawaban mareka dalam kelompok kecil. Setelah itu, hasil dari diskusi itu dibandingkan pada diskusi kelas yang dipimpin oleh guru. Pada hal ini dapat digunakan siswa untuk melatih keberanian mengemukakan pendapat, meskipun berbeda dengan teman lainnya. Dengan demikian guru mengarahkan siswa untuk menarik kesimpulan yang terkait dengan masalah kontekstual yang baru diselesaikan.

Aktivitas Guru Selama Pembelajaran. Pengamatan terhadap aktivitas guru dilakukan oleh ibu Yasnimar, SPd.SD. Berdasarkan pengamatan beliau pada siklus I taraf keberhasilan guru sudah baik. Dan siklus ke II mencapai kategori sangat baik. Adapun faktor yang menyebabkan adanya peningkatan aktivitas guru dalam pembelajaran karena guru atau peneliti selalu melakukan evaluasi pembelajaran setelah berlangsungnya proses pembelajaran, dan dipengaruhi oleh penerapan Model pembelajaran RME (Realistik Mathematics Education) dimana guru atau peneliti dinilai oleh guru melalui lembar observasi aktivitas guru. Hasil observasi tersebut dijadikan tolak ukur guru atau peneliti untuk mempertahankan yang sudah sangat baik, dan meningkatkan pada aspek yang dianggap baik dan kurang. Pembelajaran dengan penerapan Model pembelajaran RME (Realistik Mathematics Education) menunjukkan hasil yang positif dapat meningkatkan aktivitas guru. Jadi berdasarkan hal demikian maka kemampuan guru akan meningkat dengan memperbaiki kekurangan-kekurangan dari evaluasi pembelajaran. Berikut ini adalah perbandingan aktivitas guru dengan penerapan Model pembelajaran RME (Realistik Mathematics Education) pada siklus I dan siklus II disajikan dalam bentuk diagram dibawah ini. Diagram Perbandingan Aktivitas Guru.

Aktivitas Peserta Didik Selama Pembelajaran. Untuk mengamati aktivitas peserta didik selama proses pembelajaran dengan penerapan Model pembelajaran RME (Realistik Mathematics Education), peneliti meminta kesediaan ibu Yasnimar, SPd.SD. Berdasarkan hasil pengamatan terhadap peserta didik selama proses pembelajaran berlangsung yang dilakukan oleh pengamat pada siklus I. Diketahui bahwa aktivitas peserta didik selama pemebelajaran pada siklus I peserta didik masih bingung dan malu untuk bertanya. Oleh karena itu guru mengarahkan peserta didik agar fokus dalam penerapan Model pembelajaran RME (Realistik Mathematics Education), serta memotivasi peserta didik agar lebih percaya diri dalam mempresentasikan hasil diskusi di depan kelas. Setelah guru melakukan revisi pada siklus I, pada siklus II persentase aktivitas peserta didik terlihat bahwa aktivitas peserta didik dalam proses pembelajaran sudah semakin baik. Semakin sesuai dengan yang peneliti harapkan dengan waktu ideal yang telah ditentukan dalam siklus II. 
Peningkatan peserta didik dari siklus I dan II disebabkan oleh adanya penerapan Model pembelajaran RME (Realistik Mathematics Education) ini memanfaatkan otak siswa sebagai pusat untuk memperoleh informasi yang sedang dipelajari. Pembelajaran dengan penerapan Model pembelajaran RME (Realistik Mathematics Education) yang baik dan benar dapat meningkatkan aktivitas peserta didik di dalam kelas. Berdasarkan kriteria yang telah ditetapkan pada setiap aspek pengamatan dapat disimpulkan bahwa aktivitas peserta didik untuk masing-masing kategori adalah efektif. Berikut ini adalah perbandingan aktivitas peserta didik dalam mengikuti pembelajaran penerapan Model pembelajaran RME (Realistik Mathematics Education) pada siklus I dan siklus II disajikan dalam bentuk diagram di bawah ini. Diagram Perbandingan Aktivitas Peserta Didik.

Hasil Belajar Peserta Didik. Untuk melihat hasil belajar siswa pada pembelajaran melalui penerapan Model pembelajaran RME (Realistik Mathematics Education), maka peneliti mengadakan tes pada setiap akhir pembelajaran. Tes yang dilakukan setelah pembelajaran berlangsung bertujuan untuk mengetahui keberhasilan dan kemampuan peserta didik dalam memahami materi pelajaran. Setelah hasil tes terkumpul maka data tersebut diolah dengan melihat kriteria ketuntasan minimal yang berlaku di UPT. SD Negeri 09 Baringin yaitu secara individu 75 dan 85\% siswa tuntas klasikal. Hasil belajar melalui model pembelajaran penerapan Model pembelajaran RME (Realistik Mathematics Education) menunjukkan adanya peningkatan ketuntasan belajar untuk setiap siklusnya. Peserta didik yang tuntas pada siklus I berdasarkan hasil tes 12 siswa $(34,29 \%)$ dari 35 peserta didik belum tuntas hasil belajarnya, dan yang tuntas belajarnya 23 peserta didik $(65,71 \%)$. Kategori ketuntasan siswa dalam pembelajaran secara klasikal adalah jika mencapai $85 \%$ sehingga ketuntasan siswa secara klasikal pada siklus I belum tercapai. Hal ini terjadi karena kurangnya kemampuan konsentrasi dan rendahnya pemahaman siswa terhadap materi yang sedang dibelajarkan sehingga hasil belajar peserta didik ketuntasan peserta didik secara klasikal belum tercapai. Jadi untuk mengatasi hal ini, guru harus mampu meningkatkan aktivitas belajar peserta didik sehingga peserta didik selalu aktif, kreatif dan mandiri dalam mengikuti proses pembelajaran. Pada siklus II hanya 5 peserta didik $(14,29 \%)$ yang tidak tuntas belajarnya, peserta didik tuntas belajar 30 siswa $(85,71 \%)$. Kategori ketuntasan dalam pembelajaran secara klasikal adalah jika mencapai $85 \%$. Pada siklus II guru mampu memberikan motivasi belajar peserta didik sehingga peserta didik aktif dan kreatif dalam proses pembelajaran, sehingga dapat merubah hasil belajar menjadi lebih baik. Berikut ini adalah perbandingan hasil belajar peserta didik selama mengikuti pembelajaran pada siklus I dan siklus II disajikan dalam bentuk diagram dibawah ini. Diagram Perbandingan Ketuntasan Hasil Belajar Peserta Didik.

Grafik di atas menunjukan bahwa terjadi peningkatan hasil belajar siswa dimana pada post test I menjadi $65,71 \%$ meningkat ke post test II menjadi $85,71 \%$ atau dengan kata lain dari post test I ke post test II mengalami peningkatan sebesar 20\%. Dengan demikian terjadi peningkatan hasil belajar siswa mulai dari post test I hingga post test II dapat disimpulkan bahwa dengan penerapan model RME (Realistik Mathematics Education) dapat meningkatkan hasil belajar siswa khususnya pada mata pelajaran Matematika materi kecepatan di kelas V UPT. SD Negeri 09 Baringin, Kecamatan Lima Kaum Kabupaten Tanah Datar.

\section{Penutup}


Dari hasil penelitian yang telah dilakukan maka terjadi peningkatan hasil belajar Matematika siswa melalui model RME (Realistik Mathematics Education), simpulan yang diperoleh yakni: 1) Kegiatan pra tindakan untuk mengetahui yang dilakukan adalah memberikan Pre test kepada siswa untuk mengetahui kemampuan awal siswa. Dari hasil Pre Test maka diperoleh nilai rata-rata adalah 67,72. Sedangkan peserta didik yang memperoleh nilai diatas 75 hanya 48,57\% (17 peserta didik) dikatakan tuntas dan di bawah 75 hanya $81 \%$ (18 peserta didik) dikatakan belum tuntas secara keseluruhan. Penerapan model RME (Realistik Mathematics Education) dalam kegiatan pembelajaran dapat meningkatkan hasil belajar Matematika Materi Kecepatan hal ini dapat dilihat dari proses pembelajaran yang telah dilakukan bahwa peserta didik terlihat aktif, berpikir kritis, dan antusias. Keberanian siswa mulai terlihat pada saat mengemukan pendapat dan peserta didik dapat memahami pelajaran yang telah dilakukan. Setelah mengamati hasil Pre Test maka penelitian dilanjutkan pada pembelajaran siklus pertama. Siklus ini dilakukan dengan alokasi waktu 2 x 45 menit dengan materi kecepatan. Dari hasil pengamatan pada siklus pertama maka diperoleh nilai rata-rata adalah 74 . Untuk hasil belajar peserta didik secara keseluurhan diperoleh $65,71 \%$ (23 peserta didik) yang memperoleh diatas 75 (tuntas) dan 34,29\% (12 peserta didik) yang memperoleh dibawah 75 (tidak tuntas). Hasil refleksi siklus pertama adalah (1) kurang dalam artikulasi suara, (2) kurang beraprtisipasi antar siswa untuk bekerjasama pada saat berdiskusi. Karena belum mencapai ketuntasan $85 \%$ maka kegiatan penelitian dilanjutkan kegiatan pembelajaran siklus II membahas tentang menyelesaikan masalah kecepatan. Alokasi waktu 2 x 35 menit. Hasil pengamatan pada siklus ini adalah nilai rata-rata 82,86 untuk hasil belajar peserta didik secara keseluruhan diperoleh $85,72 \%$ atau 30 peserta didik memperoleh nilai diatas 75 (tuntas).

\section{Daftar Pustaka}

Afandi . Muhammad, (2013), model dan metode pembelajaran sekolah. Semarang: Unissula Press.

Aunurrahman, (2013), belajar dan pembelajaran. Bandung: Alfabeta.

Bakar. A. Rosdiana, (2012), pendidikan suatu pengantar, Bandung : Citapustaka. Media Perintis.

Djamarah . Bahri. Syaiful, Psikologi Belajar: Jakarta : Rineka Cipta.

Kunandar ,2011. Langkah mudah Penelitian Tindakan Kelas sebagai pengembangan Profesi guru, jakarta; PT. Rajawali Pers.

Khadijah, (2016), Belajar dan Pembelajaran, Bandung: Ciptapustaka Media.Khon

Mustaqim, (2008), Psikologi Pendidikan. Yogyakarta: Pustaka Pelajar.

Mardianto, 2014, psikologi pendidikan, Medan: Perdana Publishing.

Perwanto, 2011, Evaluasi Hasil Belajar, Yogyakarta, Pustaka Belajar.

Risnawati. Dan. Amir , 2016. Psikologi Pembelajaran Matematika. Yogyakarta: Aswaja Pressindo.

Sudjana, Nana. 2015.Dasar-Dasar Proses Belajar Mengajar. Bandung: Sinar

Baru Algensindo.

Shoimin. Aris, 2018, 68 Model Pembelajaran Inovatif dalam Kurikulum 2013, Jakarta: Ar-Ruzz Media.

Suprijono . Agus, (2014), cooperative learning. Yogyakarta: Pustaka Pelajar.

Soenarjo, 2007, Matematika 5 SD dan MI Kelas 5, Jakarta: Pusat Perbukuan. 
Suharsimi , Arikunto, dkk, 2006, Penelitian Tindakan Kelas ,jakarta: Bumi Aksara.

Trianto, (2009). Medesain Model Pembelajaran Inovatif-Progresif. Jakarta: Kencana.

Tirtonegoro, S. (2001) Anak supernormal dan program pendidikannya, jakarta: Bumi Aksara

Winarmi . Setyo .Endang, Dkk, 2016 Matematika Untuk SD, Bandung; PT Remaja rosdakarya.

Wahab . Rohmalina, 2016, Psikologi belajar, Jakarta, Rajawali Pers. 